\title{
Preliminary Report on the Flora of Southern Hidaka, Hokkaidô (Yezo) IV
}

By

\section{Hiroshi Hara}

With 1 Text-Figure

Received March 10, 1934

\section{Ranunculaceae}

Aconitum L.

157(1)* Aconitum corymbiferum NAKAI in Bot. Mag. Tokyo XXXI, p. 25 (1917) ; l. c. p. 224 (1917)-Tatew., Veg. Apoi p. 83 (1928)-Nakai, Veg. Apoi p. 49 (1930)

Syn. Aconitum yuparense (non TAkeda) NakaI, Veg. Apoi p. 49 (1930)

Nom. Jap. Usuba-torikabuto (NAKAI 1917).

Hab. in Mt. Apoi, Mt. Rakko, etc. Fl. Aug.-Sep.

Endemic in Yezo.

$158^{(2)}$ Aconîum lusidusculum NaKaI in Bot. Mag. Tokyo XXXI, p. 26 (1917) ; l. c. p. 226 (1917)

Nom. Jap. Teriha-bushi (NAKaI 1917).

Hab. Shoya and Saruru. Fl. late Aug.--early Sep.

Endemic in Yezo.

159(3)*Aconitum yezoense NakaI in Bot. Mag. Tokyo XXII, p. 136 (1908) ; l. с. XXXI, p. 226 (1917) (yesoense)-Tatew., Veg. Apoi p. 83 (1928)-Nakai, Veg. Apoi p. 49 (1930)

Nom. Jap. Yezo-torikabuto (NAKAI 1908).

Hab. in forests at the foot of Mt. Apoi, along Panke R. and Saruru. Fl. Aug.-Sep.

Endemic in Yezo.

Actaea L.

$160^{(4) * A c t a e a ~ a c u m i n a t a ~ W a L L i C H, ~ C a t . ~ n o . ~ 4726 ~(1830)-R o y l e, ~ I l l u s . ~}$ Bot. Himalay. Mts. I, p. 57 (1839)-Komarov, Fl. Mansh. II, p. 236 (1903) Syn. Actaea spicata L. a. melanocarpa Lebebour, Fl. Ross. I, p. 71 (1842)- 
Kegel, Tent. Fl. Ussur. p. 12 (1861)-NakaI, Veg. Apoi p. 49 (1930) Actaea spicata L. $\alpha$. nigra WiLld. 2. f. acuminata Huth in EngL. Bot. Jahr. XVI, p. 308 (1893)-NakaI, Fl. Korea. I, p. 33 (1909)

Actaea spicata L. var. nigra (non WiLLD.) auct. plur. quoad pl. ex Japon.-Tatew., Veg. Apoi p. 82 (1928)

Nom. Jap. Ruiyō-shōma.

Hab. in forests of Mt. Apoi (ex TA'TEwaki), Saruru, ete.

Dist. Shikoku, Honshu, Yezo, Korea, Manchuria, Tibet, China, Himalaya and Southern Europe.

161(5) Actaea erythrocarpa Fischer in Fischer et Meyer, Ind. Sem. Hort. Petrop. I, p. 20 (1835)-Komarov, Fl. Mansh. II, p. 237 (1903)Hultén, Fl. Kamt. II, p. 102 (1928)-Komarov, Fl. Penin. Kamt. II, p. 118 (1929)

Syn. Actaea spicata L. var. erythrocarpa Turczaninow, Cat. Baikal. no 79 (1838)-Ledeb., Fl. Ross. I, p. 71 (1.842)-Reget, Pl. Radd. I, p. 119 (1861)-Fr. Schmidt, Reis. Amur. u. Sachal. p. 32 \& 108 (1868)Huth in Engl. Bot. Jahr. XVI, p. 308 (1893)-NakaI in Bot. Mag. Tokyo XXI, p. 128 (1907)-Matsumura, Ind. Pl. Jap. II-2, p. 101 (1912)-Miyabe et Mryake, Fl. Saghal. p. 22 (1915)-Kudo, Rep. Veg. N. Saghal. p. 128 (1924)

Actaea spicata L. subsp. erythrocarpa Konsir. in Acta Hort. Petrop. XII, p. 301 (1892)

Actaea spicata L. var. rubra (non WiLld.) Boissieu in Bull. Herb.

Boiss. VII, p. 599 (1899)

Nom. Jap. Akamino-ruiyōshōma.

Hab. in forests near Shoya.

Dist. Northern Honshu, Yezo, Kuriles, Saghalien, N. Korea, Kamtchatka, Ussuri, Manchuria, Mongolia, Dahuria, Siberia and Europe.

This has the red globular bacca and the more slender pedicel than the former.

162 $2^{(6) *}$ Adonis amurensis REgeL et RADDE in REGEL, Pl. Radd. I, p. 35 \& 36, tab. II fig. 1, 2, a, b (1861)-Kudo, Rep. Veg. North. Saghal. p. 139 (1924)-Tatew., Veg. Apoi p. 84.(1928)-Nakai, Veg. Apoi p. 49 (1930); in Bot. Mag. Tokyo XLV, p. 116 (1931)-Komarov et Klobukova-Alisova, Key P1. Far East. Reg. USSR. I, p. 563, t. 171-172 (1931)

Syn. Adonis amurensis Reg. et Rad. a. uniflorus Makino in Bot. Mag. Tokyo XV, p. 97 (1901)

Adonis amurensis var. yezoensis Kudo, Medic. Pl. Hokkaido pl. 44 (1922) 
Nom. Jap. Fukujusō, Oku-fuikujusō (Kudo 1922), Amur-fukujusō (Kudo 1924).

Hab. Mt. Apoi (ex Tatewaki), Shoya, ete. Fruit May.

Dist. Kyushu, Honshu, Yezo, Saghalien, Korea, Manchuria and Amur.

Anemone L.

163 ${ }^{(7) * A n e m o n e ~ d e b i l i s ~ F i s c i n e r ~ a p u d ~ T u r c z . ~ i n ~ B u l l . ~ S o c . ~ N a t . ~ M o s e . ~}$ XXVII-2, no. IV, p. 273 (1854)-Hultén, Fl. Kamt. II, p. 109 (1928)Komarov, Fl. Penin. Kamt. II, p. 130 (1929)

Syn. Anemone gracilis Fr. Schm. var. debilis Kordz. in Bot. Mag. Tokyo

XXXI, p. 139 (1917)

Nom. Jap. Hime-ichige.

Hab. on Mt. Rakko and Shoya. Fl. May.

*var. gracilis (ScIllechtendal) Hara, comb. nov.

Syn. Anemone ranunculoides L. $\beta$. gracilis Schlechtendal in Linnaea VI, p. $574(1831)$

Anemone caerulea DC. var. gracilis Ledeb., Fl. Ross. I, p. 14 (1842) Anemone linearis Schlechtd. ex Ledeb., l. c. pro syn.

Anemone gracilis Fr. Schmidt, Reis. Amur. u. Sachal. p. 102 (1868)-

Kudo, Rep. Veg. N. Saghal. p. 131 (1924)-Tatew., Veg. Apoi p. 83 (1928)-Nakai, Veg. Apoi p. 49 (1930)

Anemone coerulea ssp. gracilis var. linearis UlbRICH in ENGL., Bot.

Jahrbuch. XXXVII, p. 218 (1906)

Anemone gracilis Fr. Schm. var. linearis KorDz. in Bot. Mag. Tokyo XXXI, p. 139 (1917)

Anemone debilis Fisch. var. linearis Makino et Nemoto, Fl. Jap. ed.

1, p. 961 (1925); ed. 2, p. 316 (1931)

Nom. Jap. Hosoba-himeichige (KoIdzumi 1917).

Hab. on Mt. Apoi, Shoya, etc. Fl. May.

Dist. sp. Kyushu, Honshu, Yezo, Kuriles, Saghalien, Ussuri, Ajan, Kamtchatka and Bering Straits.

164 ${ }^{(8) *}$ Anemone flaccida Fr. Scimidt, Reis. Amur. u. Sachal. p. 103 (1868)-Kudo, Rep. Veg. N. Saghal. p. 132 (1924)-Tatew., Veg. Apoi p. 83 (1928)-Nakai, Veg. Apoi p. 49 (1930)

Syn. Anemone baicalensis Turcz. var. laevigata A. Gray in Perry's Narr: Exp. Jap. II, p. 306 (1857)

Anemone laevigata KoIdzumi in Bot. Mag. Tokyo XLIII, p. 395 (1929)

Nom. Jap. Nirinsō. 
Hab. in the lower part of Mt. Apoi, Samani, Shoya, ete. Fl. May.

Dist. Honshu, Yezo, Saghalien, Korea, China, Manchuria and Amur.

I sometimes found a monstrous form which has green flowers, $A$. flaccida Fr. Schm. f. viridis Tatewaki in Resear. Bull. Exp. For. Hokkaido Imp. Univ. VII, p. 191 (1932).

165 ${ }^{(9)}$ Anemone narcissiflora Linnaeus, Sp. Pl. ed. 1, p. 542 (1753) (ut narcissifolia)

Nom. Jap. Hakusan-ichige.

Hab. in the upper part of the ridge between Mt. Rakko and Mt. Tokachi.

Dist. Central \& Northern Honshu, Yezo, Kuriles, Saghalien, Kamtchatka, Korea, China, Dahuria, Siberia, Altai, Himalaya, Asia Minor, Europe and N. America.

This species is very variable in all respects. In the plant on the Hidaka range, the lobes of the leaves have the acute apex and the pedicels are slender.

166 ${ }^{(10)}$ *Anemone Raddeana RegeL, Pl. Radd. I, p. 16, tab. I, fig. 2, 3, f, g (1861)-Matsumura, Ind. Pl. Jap. II-2, p. 105 (1912)-Miyabe et Miyake, Fl. Saghal. p. 9 (1915)-Tatew., Veg. Apoi p. 83 (1928)-NakaI, Veg. Apoi p. 49 (1930)

Nom. Jap. Adzuma-ichige (Makino 1897).

Hab. Mt. Apoi, Shoya, etc. Fl. early May.

Dist. Honshu, Yezo, Saghalien, Korea, China, Manchuria and Amur. Aquilegia L.

167(11)*Aquilegia japonica NaKaI et Hara, sp. nov. ${ }^{1)}$

Syn. Aquilegia flabellata (non Sieb. et Zucc.) Fr. Schmidt, Reis. Amur. u. Sachal. p. 106 (1868)-Miyabe et Mryake, Fl. Saghal. p. 19 (1915)

1) Aquilegia japonica NAKAI et HARA

f. globularis (HoNDA et KISHINAMI) NAKAI et HARA, comb. nov.

Syn. Aquilegia akitensis Huth. f. globularis Honda et Kishinami in Bot. Mag. Tokyo XLVII, p. 433 (1933)

Nom. Jap. Tamazaki-miyamaodamaki (HoNDA).

Hab. Honshu.

var. flavida (NAKAI) NAKAI et HARA, comb. nov.

Syn. Aquilegia ahitensis Huth var. flavida NakAI in Bot. Mag. Tokyo XLIV, p. 39 (1930)

Nom. Jap. Kibana-miyamaodamaki (NAKAI)

Hab. Korea. 
Aquilegia Buergeriana var. pumila Huтн in Bull. Herb. Boiss. V, p. 1090 (1897)

Aquilegia glandulosa (non Fiscier) Borssiev in Bull. Herb. Boiss. VII, p. 597 (1899) pro parte.

Aquilegia akitensis (non Hutri) Makino in Bot. Mag. Tokyo XVII, p. 10 (1903)-Matsumura, Ind. Pl. Jap. II-2, p. 106 (1912)-Tatew., Veg. Apoi p. 82 (1928)-Nakai in Bot. Mag. Tokyo XLIV, p. 38 (1930); Veg. Apoi p. 49 (1930)

Aquilegia sibirica var. flabellata Finet et Gagn. in Bull. Soc. Bot. France LI, p. 412 (1904) pro parte-Takeda in Bot. Mag. Tokyo XXIV, p. 236 (1910)-Matsumura, l. c. (1912) pro parte.

Aquilegia Fauriei (non Léveillé 1902) LÉv. et VNT. ex LÉv. in Bull. Soc. Bot. France LIII, p. 389 (1906)-Matsumura, 1. c. (1912)

Aquilegia flabellata f. pumila Kudo, Rep. Veg. N. Saghal. p. 129 (1924)

Aquilegia flabellata var. pumila Kudo in Rep. Exper. Forest Kyushu Imp. Univ. I, p. 65 (1931)

Aquilegia flabellata var. pumila OHwi in Acta Phytotax. et Geobot. III, p. 116 (1934)

Columna rhizomatis perennis crassa. Folia radicalia longe petiolata, petiolis basi vaginatis parce molliter hirsutis, ternata, petiolulis gracilibus parce hirsutis; lamina trisecta subtus parce molliter hirsuta flabellata tripartita, lobis vulgo 1-3-rotundato-incisis. Caulis $10-40 \mathrm{~cm}$. altus $1-3-$ florifer praesertim apice molliter hirsutus vulgo 1-3-foliatus, foliis infimis interdum radicalibus conformibus, supremis parvis saepe bracteiformibus. Flores pulchri. Sepala petaloidea caeruleo-purpurea elliptica vel late elliptica apice rotundata vel obtusa usque ad $3 \mathrm{~cm}$. longa $1.5 \mathrm{~cm}$. lata. Petala apice lutescentia basi purpurascentia linguiformia apice rotundata sepalis distincte breviora. Calcar $8-20 \mathrm{~mm}$. longa ad apicem sensim attenuata apice rectiuscula vel incurva: Stamina numerosa, interiora ad staminodia membranacea transformantia. Ovaria primo parce hirsuta demum glabra, stylis filiformibus persistentibus. Folliculi erecti 1.5-2.5 cm. longi nervosi. Semina numerosa fusiformia ca. $2 \mathrm{~mm}$. longa nigra sub lente minutissime rugulosa.

Nom. Jap. Miyama-odamaki (Makino 1903), Oku-miyama-odamaki (Kudo).

Hab. in the upper part of Mt. Apoi, Mt. Horoman and Mt. Rakko Fl. June.

Typus. Honshu: prov. Shinano: in monte Shirouma (S. KodAmaAug. 20, 1908)

Dist. Cent. \& North. Honshu, Yezo, Kuriles, Saghalien and Korea. 
Aquilegia flabellata Siebold et Zuccarini differs from this species by robust and glaucous stems and leaves, always incurved spur, more bluish sepals, petals white at the apex, etc. In the Koishikawa Botanic Gardens, specimens of this species either transplanted from the mountain or raised from the seeds, have been cultivated for many years, but their characteristies are always constant and are never confused with those of A. flabellata.

\section{Callianthemum C. A. Meyer}

168(12)* Callianthemum insigne NAKAI in Scientific Knowledge VIII-1, p. 41 (1928); Veg. Apoi p. 34 \& 49 (1930)-OHwi in Acta Phytotax. e Geobot. I, p. 301 (1932) pro parte.

Syn. Isopyrum insigne NakaI in Bot. Mag. Tokyo XXXIII, p. 49 (1919)

Anemone insignis NakaI in Matsumura, Icon. Pl. Koisik. IV, p. 85, pl. 255 (1921)

Callianthemum Miyabeanum Tatewaki in Trans. Sapporo Nat. Hist.

Soc. X-1, p. 79 (1928); Veg. Apoi p. 83 \& 129 (1928)-Makino et

Nemoto, Fl. Jap. ed. 2, p. 320 (1931)

Nom. Jap. Umezalii-sabanoo (Nakai 1919), Ume-ichige (Nakai 1921), Hidaka-sō (TАTEWAKI 1928)

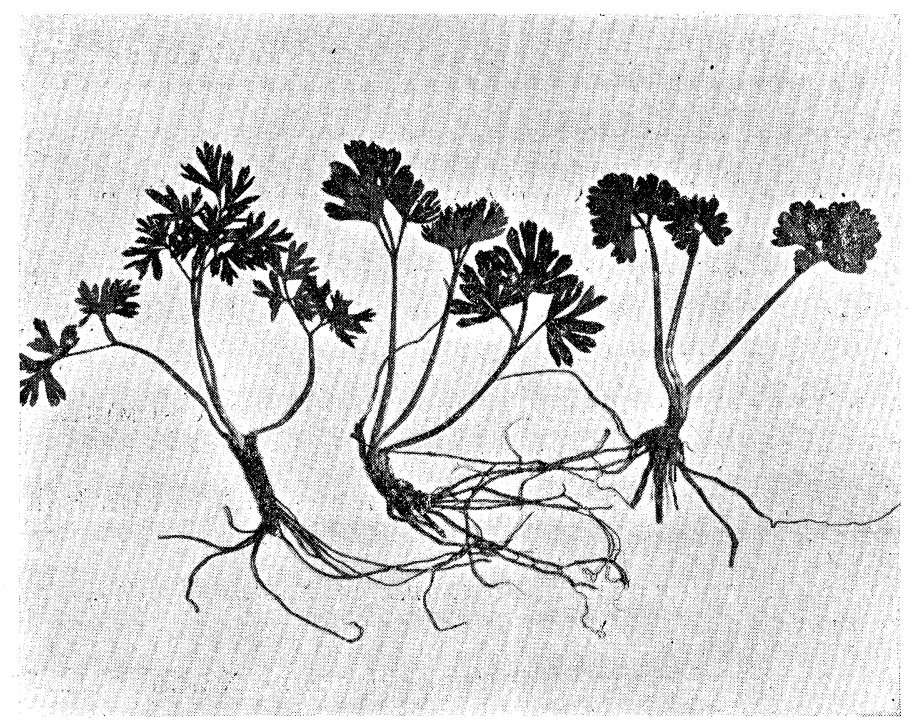

Fig. 10. Callianthemum insigne NakaI from Mt. Apoi.

Hab. on gravelly slopes in the upper part of Mt. Apoi and Mt. Horoman. Fl. late May-early Jun.

Dist. Yezo (Mt. Apoi and Mt. Horoman) and North Korea.

The variability in the shape of the leaves was already pointed out in 
the Journal of Japanese Botany X, p. 677 (1934) (cf. Fig. 10). The type specimen of $C$. Miyabeanum is a dwarf broad-leaved form.

\section{Caltha L.}

$169^{(13)}$ Caltha fistulosa N. Schipczinsky in Not. Syst. Hort. Bot. Petrop. II, p. 166 (1921)

Syn. Caltha palustris L. var. Barthei Hance in Ann. Sci. Nat. ser. 5, V, p. 205 (1866) fide Dr. KoIdzumi.

Caltha palustris L. var. typica (non Regel) Fr. ScHmidt, Reis. Amur. u. Sachal. p. 105 (1868)-Makino in Bot. Mag. Tokyo XIII, p. [200] (1899); l.c. XXII, p. 176 (1908)-NAKaI in Bot. Mag. Tokyo XXI, p. 127 (1907)-Matsumura, Ind. Pl. Jap. II-2, p. 107 (1912)-Miyabe et Miyake, Fl. Saghal. p. 16 (1915)

Caltha palustris L. f. gigas LéveILlé in Fedde, Rep. Sp. Nov. VII, p. 102 (1909)-Kudo, Rep. Veg. North. Saghal. p. 127 (1924)

Caltha palustris L. var. gigas TAKEDA, Fl. Shikotan in Journ. Linn. Soc. XLII, p. 450 (1914)

Caltha Barthei KoIdzumi, Fl. Symb. Or.-Asia. p. 77 (1930)

Nom. Jap. Yezo-ryūkinkwa (Makino 1899).

Hab. along Panke R.

Dist. Yezo, Kuriles, Saghalien, Korea and Eastern Siberia.

170(14)*Cimicifuga yesoensis Kudo, Contr. North. Saghal. p. 36 (1923); Rep. Veg. N. Saghal. p. 129 (1924) (ut yezoensis)-Tatew., Veg. Apoi p. 82 (1928)

Syn. Cimicifuga simplex (non Wormskjord) Fr. Schmidt, Reis Amur. u. Sachal. p. 109 (1868)-Miyabe et Mryake, Fl. Saghal. p. 23 (1915)

Cimicifuga foetida L. var. intermedia (non Reges) Huth in Bull. Herb. Boiss. V, p. 194 (1897) pro parte-Matsumura, Ind. Pl. Jap. II-2, p. 107 (1912) pro parte.

Cimicifuga simplex Wormsk. var. yesoensis NakaI in Bot. Mag. Tokyo XXX, p. 146 (1916)

Cimicifuga simplex var. Matsumurai NakaI f. villosa NaKaI, l. c. p. 147 (1916) pro parte.

Cimicifuga simplex var. intermedia (non Nakai 1916) NakaI, Veg. Apoi p. 49 (1930)

Haec planta ex $C$. simplex caule elatiore, foliis majoribus latioribus multo herbaceis, inflorescentia ramosa atque racemis apice nutantibus abhoret.

Nom. Jap. Yezo-shōma (Nakai 1916).

Hab. in forests of Mt. Apoi, Saruru-sandō, etc. Fl. Sep. 
Dist. N. Honshu, Yezo, Kuriles, Saghalien and Kamtchatka?

Clematis L.

171(15)*Clematis fusca Turczaninow in Bull. Soc. Nat. Mosc. XIII, p. 60 (1840)-Ledebour, Fl. Ross. I, p. 725 (1842)-Maximowicz in Bull. Acad. Imp. Sci. St.-Pétersb. XXII, p. 213 (1876) pro parte-Hultén, Fl. Kamt. II, p. 117 (1928)-Komarov, Fl. Penin. Kamt. II, p. 150 (1929)

Syn. Clematis kamtschatica Bongard in Bong. et Meyer, Verz. Saisang-Nor u. Irtysch. gesam. Pfl. p. 10 (1841)

Clematis fusca var. kamtschatica Regel et Tiling, Fl. Ajan. p. 19 (1858)-REgeL, Tent. Fl. Ussur. p. 2 (1861) ; Gartenfl. XIII, p. 356 in nota (1864)-TAKEDA in Bot. Mag. Tokyo XXIV, p. 237 (1910)

Clematis fusca $\alpha$. normalis O. Kuntze, Monogr. Clemat. p. 132 (1885)

Clematis fusca var. typica ScHneID., Ill. Handb. Laubholzk. I, p. 279 (1904)

var. yezoensis Mryabe in sched. apud Makino in Bot. Mag. Tokyo XI, p. [332] (1897) nom. nud.-Takeda, 1. c. pro syn.-Matsumura, Ind. Pl. Jap. II-2, p. 111 (1912)-Nakar in Bot. Mag. Tokyo XXXIV, p. 43 (1920) pro parte (sphalmate yeseonsis).

Syn. Clematis fusca (non Turcz.) Franciiet et Savatier, Enum. Pl. Jap. II-1, p. 262 (1876)-Huti in Bull. Herb. Boiss. V, p. 1064 (1897)Matsum., l. c. (1912)

Clematis fusca var. mandshurica (non Regel) Takeda in Bot. Mag. Tokyo XXIV, p. 237 (1910) excl. syn.

Clematis fusca var. kamtschatica (non Regel et Tiling) Tatewaki, Veg. Apoi p. 83 (1928)

Clematis kamtschatica (non Bongard) NakaI, Veg. Apoi p. $20 \& 49$ (1930)

Nom. Jap. Kurobana-hanshōdzuru, Yezo-hanshōdzuru.

Hab. on grassy slopes of Mt. Apoi and Mt. Horoman. Fl. Jul.

Dist. Honshu?, Yezo and Saghalien.

The Japanese plant is quite different from that of Manchuria and Korea, and its peduncle sometimes attains $20 \mathrm{~cm}$. long. "The good description was given by Dr. TAKEDA under the name of $C$. fusca var. mandshurica, l. c.

172 ${ }^{(16) *}$ Clematis ochotensis PoIRET, Encycl. Suppl. II, p. 298 (1811)-DC., Prodr. I, p. 10 (1824)-Komarov, Fl. Penin. Kamt. II, p. 151 (1929)-NakaI, Veg. Apoi p. 49 (1930)

Syn. Atragene ochotensis Pallas, Fl. Ross. I-2, p. 69 (1788)

Atragene alpina L. var. ochotensis Regel et Tiling, Fl. Ajan. p. 20 \& 23 (1858)-NakaI in Bot. Mag. Tokyo XXI, p. 123 (1907) 
Clematis alpina MiLL. var. ochotensis O. Kuntze, Monogr. Clemat. p. 163 (1885)

Clematis alpina (non Miller) Huth in Bull. Herb. Boiss. V, p. 1065 (1897) pro parte-Matsumura, Ind. Pl. Jap. II-2, p. 108 (1912) pro parte.

Clematis alpina Milu. var. ochotensis Regel et Tiling apud Makino in Bot. Mag. Tokyo XI, p. [330] (1897) nom. nud.-Miyabe et Miyake, Fl. Saghal. p. 3 (1915)-Kudo, Rep. Veg. N. Saghal. p. 134 (1924)-IIultén, Fl. Kamt. II, p. 118 (1928)-Tatew., Veg. Apoi p. 83 (1928)

Clematis alpina MiLl. var. normalis (non O. Kuntze) Borssieu in Bull. Herb. Boiss. VII, p. 583 (1899) pro parte-Matsumura, l. e. p. 109 (1912) pro parte.

Clematis alpina Mill. var. ochotensis Finet et GaGN. in Bull. Soc. Bot. France L, p. 552 (1903)

Clematis ochotensis PoIRET var. grandidentata NakaI, Veg. Apoi p. 50 (1930) nom. nud.

Nom. Jap. Yezo-miyama-hanshōdzuru.

Hab. in Mt. Apoi, Mt. Rakko, ete. Fl. late May-early Jul.

Dist. Honshu, Yezo, Kuriles, Saghalien, Korea, Manchuria, Ochotsk, Amur and Kamtchatka.

Variety grandidentata is a form which has the oblong leaflets with few big teeth.

Ranunculus L.

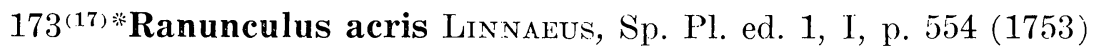

var. frigidus REgeL, Tent. Fl. Ussur. p. 7 in adnota (1861)

Hab. in Mt. Horoman, C. Erimo, ete. Fl. Jun.-Jul.

Dist. Yezo, Kuriles, Saghalien, Korea, Manchuria, Ussuri, Amur and Kamtchatka.

It is doubtful if this plant is identical with $R$. acris var. Steveni in Tatew., Veg. Apoi p. 84 and Nakai, Veg. Apoi p. 50.

$174^{(18)}$ * Ranunculus Vernyi Franchet et Savatier, Enum. Pl. Jap. I, p. 8 (1874) nom. nud.; II-1, p. 266 (1876)-KoIdzumi, Fl. Symb. Or.-Asia. p. 78 (1930)-NakaI, Veg. Apoi p. 50 (1930)

*var. glaber NaKaI in Bot. Mag. Tokyo XLII, p. 19 (1928)

Syn. Ranunculus japonicus var. glaber BoIssieu in Bull. Herb. Boiss. VII, p. 594 (1899)

Ranunculus glaber MaKino in Journ. Jap. Bot. VII-10, p. 31 (1932)

Nom. Jap. Kitsune-no-botan. 
Hab. at the foot of Mt. Apoi, etc. Fl. Jul.

*var. quelpaertensis NAKAI, 1. c. p. 21 (1928) ; Veg. Apoi p. 50 (1930)

-Tatew., Veg. Apoi p. 84 (1928)

Nom. Jap. Yama-kitsunenobotan (NAKAI)

Hab. along Horoman $\dot{R}$., Nikanbetsu R., etc.

Dist. sp. Formosa, Liukiu, Kyushu, Shikoku, Honshu, Yezo, Kuriles, Korea and China.

\section{Thalictrum L}

$175^{(19)}$ Thalictrum aquilegifolium Linnaeus, Sp. Pl. ed. 1, I, p. 547 (1753)-Kudo, Rep. Veg. N. Saghal. p. 138 (1924)-Hultén, Fl. Kamt. II, p. 134 ( 1928)-Komarov, Fl. Penin. Kamt. II, p. 154 (1929)

Nom. Jap. Karamatsusō.

Hab. in Mt. Ruchishi, Mt. Toyoni. Fl. Jun.

Dist. Honshu, Yezo, Saghalien, Korea, Ochotsk, Kamtchatka, Manchuria, Amur, Dahuria and Europe.

$176^{(20)} *$ Thalictrum integrilobum Maximowicz in Bull. Acad. Imp. Sci. St.-Pétersb. XXXII, p. 477 (1883)-Matsumura, Ind. Pl. Jap. II-2, p. 123 (1912)-Tatew., Veg. Apoi p. 84(1928)-Nakai, Veg. Apoi p. 20 \& 50(1930)

Nom. Jap. Nagaba-karamatsusō, Samani-karamatsu.

Hab. in valleys of Mt. Apoi, Mt. Horoman. Fl. Jun.

Endemic in Yezo (prov. Hidaka and Iburi).

This species is near to T. tuberiferum Maximowicz, and has the tubercles on roots as in the latter.

177(21)* Thalictrum Thunbergii A. P. de Candolle, Syst. Nat. I, p. 183 (1818)-Nakai in Bot. Mag. Tokyo XLII, p. 1 (1928)

*var. majus Nakai, l. c. p. 4 (1928) ; Veg. Apoi p. 50 (1930)-TAtew., Veg. Apoi p. 84 (1928)

Nom. Jap. Yezo-aki-karamatsu.

Hab. in the lower part of Mt. Apoi. Fl. Aug.

**var. divaricatum NAKAI, l. c. p. 5 (1928)

Nom. Jap. $\bar{O}$-karamatsu.

Hab. in the lower part of Mt. Apoi, Mt. Ruchishi. Fl. Jul.-Aug.

***var. temuipes NaKaI, l. c. p. 5 (1928)

Nom. Jap. Usuba-karamatsu.

Hab. in Mt. Apoi, Mt. Horoman. Fl. Jul.

Dist. sp. Kyushu, Shikoku, Honshu, Yezo, Kuriles, Saghalien, Korea, China, Manchuria, Ussuri, Kamtchatka, Amur and Dahuria.

This species is very polymorphous and the distinetion between the 
varieties above mentioned is not clear. Some of them rather resemble to var. hypoleucum NAKAI.

$178^{(22)}$ * Thalictrum yesoense NAKAI in Bot. Mag. Tokyo XLII, p. 6(1928); Veg. Apoi p. 50 (1930)-Thtew., Veg. Apoi p. 84 (1928)

Syn. Thalictrum foetidum L. var. glabrescens. TAkeda apud TATEw., Veg. Apoi p. 84 (1928)

Nom. Jap. Ko-karamatsu, Chabo-karamatsu.

Hab. on rocks in the upper part of Mt. Apoi, Mt. Horoman and Aburakoma. Fl. Jun.

Endemic in Yezo.

'Shakotan' where FAURIE collected many interesting plants is not situated in Kuriles, but is in the province of Shiribeshi of Yezo. And this plant has not been recorded from Kuriles as yet.

This species resembles to a dwarf form of $T$. Thunbergii, but is more glaucous in all parts than the latter and sparsely glandular under the lens. Its leaves are arcuately divaricate and 5-6-(sometimes 4- or 7-)ternatepinnate. Its leaflets are very small, $3-7 \mathrm{~mm}$. long (rarely attain $1 \mathrm{~cm}$. long), with nerves strikingly impressed on the upper surface, and minutely and densely papillose especially on the underside. It flowers a month or more earlier than T. Thunbergii at the same locality. Its pedicels are long; its carpels sessile, ellipsoid, 3-4 mm. long, with 8 longitudinal costae.

Trautvetteria Fischer et MEyer

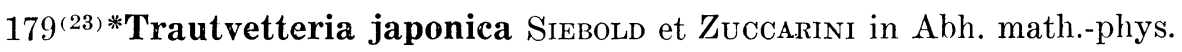
Akad. Wiss. Muenchen IV-2, p. 184 (1845)-Tatew., Veg. Apoi p. 83 (1928)-NakaI, Veg. Apoi p. 50 (1930); in Bot. Mag. Tokyo XLV, p. 117 (1931)

Syn. Trautvetteria palmata (non Fiscirer et Meyer) Miquel in Ann. Mus. Bot. Lugd.-Bat. III, p. 4 (1867)-Franchet et Savatier, Enum. Pl. Jap. I, p. 6 (1874)

Trautvetteria palmata $\gamma$. japonica HuTH in ENGLER, Bot. Jahrb. XVI, p. 288 (1893)-Makino in Bot. Mag. Tokyo VIII, p. [377] (1894)Huth in Bull. IIerb. Boiss. V, p. 1071 (1897)-Boissieu in Bull. Herb. Boiss. VII, p. 588 (1899)-Matsumura, Ind. Pl. Jap. II-2, p. 125 (1912)

Trautvetteria palmata var. minor LÉveILlé et VANIOT ex LÉv. in Bull. Soc. Bot. France LIII, p. 388 (1906)

Nom. Jap. Momiji-karamatsu.

Hab. along Horoman R. and Mt. Rakko.

Dist. Honshu, Yezo and Kuriles. 
This species is considerably variable in the shape of the leaves and the achenes. The plant of Honshu and South Yezo has always quite glabrous leaves and generally distinct styles, but in some individuals from Kuriles, the leaves are very sparsely hairy on the underside veins. The achenes are glabrous or sometimes sparsely hairy along the costa with white stiff hairs.

The plant of Saghalien is usually hairy on the underside veins of the leaves with long white stiff hairs, and the style is shorter, and it comes nearer to $T$. carolinensis VEIL of N. America. But taking its geographical distribution into consideration, I want to treat it as a variety ${ }^{2)}$ of $T$. japonica.

\section{Podophyllaceae}

\section{Diphylleia Michaux}

180(1) Diphylleia Grayi Fr. Schмidt, Reis. Amur. u. Sachal. p. 109 (1868) -Takeda in Bot. Mag. Tokyo XXIV, p. 254 (1910)-Matsumura, Ind. Pl. Jap. II-2, p. 130 (1912)-Miyabe et Miyake, Fl. Saghal. p. 27 (1915)

Nom. Jap. Sankayō.

Hab. in forests near Shoya, in Mt. Rakko, etc. Fl. May.

Dist. Honshu, Yezo and Saghalien.

Glaucidium Sieb. et Zucc.

181 (2)*Glaucidium palmatum SieBold et ZUCCARINI in Abh. math.-phys. Kl. Akad. Wiss. Muenchen IV-2, p. 184 tab. I, B (1845)-Matsumura, Ind. Pl. Jap. II-2, p. 116 (1912)-Tatew., Veg. Apoi p. 82 (1928)-NaKaI, Veg. Apoi p. 50 (1930)

Nom. Jap. Shirane-aoi.

2) Trautvetteria japonica SIEBOLD et ZUCCARINI var. borealis HARA, var. nov.

Syn. Trautvetteria palmata Fischer et Meyer, Ind. Sem. Hort. Petrop. I, p. 22 (1835) pro parte-Trautv. et Mey., Fl. Ochot. p. 21 (1847)-Korshinsky in Acta Hort. Petrop. XII, p. 301 (1892)

Ranunculus pleurocarpus Maximowicz, Prim. Fl. Amur. p. 21 (1859)

Trautvetteria japonica (non Sieb. et Zucc.) Fr. Schmidt, Reis. Amur. u. Sachal. p. 30 \& p. 108 (1868)-Komarov, Fl. Mansh. II, p. 303 (1903)Miyabe et Miyake, Fl. Saghal. p. 11 (1915)-Kudo; Contr. N. Saghal. p. 37 (1923) ; Rep. Veg. N. Saghal. p. 135 (1924)

Differt a typo foliis subtus secus venas pilosis, pilis albis longis rigidulis, et stylis brevioribus.

Nom. Jap. Oku-momiji-karamatsu (nov.)

Hab. Sachalin: in monte Suzuya (H. HARA)-in monte Tosso (H. HARA)in monte Ishiyama prope Shiretori (H. HARA).

Yezo: prov. Kitami: ad rivulum in monte Poronupri (H. HARA)

Dist. Yezo borealis, Sachalin, Ochotsk et Amur. 
Hab. at the foot of Mt. Apoi, Shoya, etc. Fl. May.

Dist. Honshu and Yezo.

\section{Berberidaceae}

Berberis L.

$182^{(1) * B e r b e r i s}$ amurensis RUPRECHT in Bull. phys.-math. Acad. St.Pétersb. XV, p. 260 (1857)-Schneider in Bull. Herb. Boiss. ser. 2, V, p. 665 (1905)-Nakai, Veg. Apoi p. 50 (1930)-Komarov et KlobukovaAlisova, Key Pl. Far East. Reg. USSR. I, p. 564, tab. 173. III (1931)

Syn. Berberis vulgaris var. amurensis REGEL in Pl. Maak. p. 14; in Acta Hort. Petrop. II, p. 414 (1873)

Berberis vulgaris var. japonica REGeL, l. c. p. 415 (1873)-Iто in Journ. Linn. Soc. Bot. XXII, p. 427 (1887)-Makino in Bot. Mag. Tokyo X, p. [250] (1896)-Matsumura, Ind. Pl. Jap. II-2, p. 129 (1912)

Berberis Sieboldi (non Miquel) Iто, l. c. pro parte.

Berberis japonica (non R. BR.) Schneider, Ill. Handb. Laubholzk. I, p. 315 (1905) ; in Bull. Herb. Boiss. ser. 2, V, p. 667 (1905)

Berberis Regeliana Koehne ex Schneider, 1. c. p. 315 in adnota (1905) ; 1.c. p. 667 in adnota (1905)-TATEw., Veg. Apoi p. 85(1928)

Nom. Jap. Hiroha-no-hebinoborazu, Ōba-no-hebinoborazu.

Hab. in Mt. Apoi and Mt. Horoman. Fl. Jun.

Dist. Honshu, Yezo, Korea, Manchuria and Amur.

\section{Caulophyllum Michaux}

183(2)*Caulophyllum robustum Maximowicz, Prim. Fl. Amur. p. 33 (1859)-Miyabe et Miyake, Fl. Saghal. p. 27 (1915)-Kudo, Rep. Veg. N. Saghal. p. 140 (1924)-Tatew., Veg. Apoi p. 84 (1928)-Komarov et Klobukova-Alisova, Key Pl. Far East. Reg. USSR. I, p. 564, tab. 173. II (1931)

Syn. Caulophyllum thalictroides (non Michaux) Iто in Journ. Linn. Soc. XXII, p. 428 (1887)-Matsumura, Ind. Pl. Jap. II-2, p. 129 (1912)

Nom. Jap. Ruiyō-botan.

Hab. in forests of Mt. Apoi, Shoya, etc. Fl. May.

Dist. Kyushu, Shikoku, Honshu, Yezo, Saghalien, Korea, China, Manchuria, Ussuri and Amur.

\section{Magnoliaceae}

Magnolia L.

184(1)*Magnolia kobus A. P. de Candolle, Syst. Nat. I, p. 456 (1818)- 
NakaI, Veg. Apoi p. $20 \& 50$ (1930); Fl. Sylv. Korea. XX, p. 120, tab. XXIV (1933)

Nom. Jap. Kobushi.

Hab. in the lower part of Mit. Apoi. Fl. May.

*var. borealis Sargent, Trees and Shrubs II, p. 57 (1908)-Miyabe et Kudo, Icon. Essent. For. Tree. Hokkaido II-15, p. 29, t. 45 (1927)Tatew., Veg. Apoi p. 85 (1928)-Nakai, Veg. Apoi p. 50 (1930)

Syn. Magnolia borealis Kudo, Medic. Pl. Hokk. t. 47 (1922)

Nom. Jap. Kita-kubushi.

Hab. in the lower part of Mt. Apoi, Shoya, etc. Fl. May.

Dist. sp. Kyushu, Shikoku, Honshu, Yezo and Quelpaert.

185 (2)* Magnolia obovata Thunberg in Trans. Linn. Soc. II, p. 336 (1794) -Miyabe et Kudo, Icon. Essent. For. Tree. Hokkaido II-15, p. 27, t. 44 (1927)-Tatew., Veg. Apoi p. 85 (1928)-Koidzumi in Bot. Mag. Tokyo XLIV, p. 109 (1930)-Nakai, Veg. Apoi p. 50 (1930)

Nom. Jap. Hô-no-ki.

Hab. in the lower part of Mt. Apoi, etc. Fl. Jun.

Dist. Liukiu, Kyushu, Honshu, Yezo, Southern Kuriles and China.

\section{Schizandra Michaux}

$186^{(3)}$ *Schizandra chinensis BAILLON, Hist. Pl. I, p. 148 (1868)-TATEW., Veg. Apoi p. 85 (1928)-Nakai, Veg. Apoi p. 50 (1930)-Komarov et Klobukova-Alisova, Key Pl. Far East. Reg. USSR. I, p. 523, t. 159 (1931) -NakaI, Fl. Sylv. Korea. XX, p. 103, tab. XX (1933)

Syn. Kadsura chinensis Turczaninow in Bull. Soc. Imp. Nat. Mose. VII, p. 149 (1837)

Nom. Jap. Chôsen-gomishi.

Hab. in the lower part of Mt. Apoi, Shoya, etc. Fl. Jun.

Dist. Honshu, Yezo, Southern Kuriles, Saghalien, Korea, China, Manchuria, Ussuri and Amur.

\section{Fumariaceae}

Corydalis DC.

187 (1)*Corydalis ambigua Cinamisso et Schlechtendal in Linnaea I, p. 558 (1826)-Takeda in Bot. Mag. Tokyo XXIV, p. 7 (1910)-Kudo, Fl. Paramush. p. 110 (1922)-Tatew., Veg. Apoi p. 85 (1928)-IIultén, Fl. Kamt. II, p. 142 (1928)-Komarov, Fl. Penin. Kamt. II, p. 159 (1929)NakaI, Veg. Apoi p. 50 (1930)

Nom. Jap. Yezo-engosaku (Makino 1894).

Hab. at the foot of Mt. Apoi, Shoya, etc. Fl. May. 
Dist. sp. Yezo, Kuriles, Saghalien, Korea, Ochotsk and Kamtchatka.

At Shoya, I collected some specimens which belong to var. genuina f. lineariloba TAKeda, l. c. p. $8(1910)\{=C$. ambigua $\beta$. amurensis 1. 2. linearilobus Maxim., Prim. Fl. Amur. p. 37 (1859); C. ambigua var. stenoloba Franchet ex Boiss. in Bull. Soc. Bot. France XLVII, p. 314 (1900); C. ambigua var. angustifolia YATABE, Nippon-shokubutsuhen I, p. $121(1900)\}$.

$188^{(2)}$ * Corydalis Maximowicziana NakaI in Bot. Mag. Tokyo XXXIII, p. 51 (1919)-Kudo, Rep. Veg. N. Saghal. p. 142 (1924)-Tatew., Veg. Apoi p. 85 (1928)-Nakai, Veg. Apoi p. 51 (1930)-Komarov et KlobukovaAlisova, Key Pl. Far East. Reg. USSR. I, p. 576, tab. 176, 5 \& 7 (1931)

Nom. Jap. Yezo-kikeman.

Hab. in the lower part of Mt. Apoi, Shoya, etc. Fl. May.

Dist. Honshu, Yezo, Southern Kuriles, Saghalien, Korea, Manchuria, Ussuri and Amur.

$189^{(3)}$ * Corydalis ochotensis Turczaninow in Bull. Soc. Imp. Nat. Moseou XIII, p. 62 (1840)-Kudo, Rep. Veg. N. Saghal. p. 142 (1924)-Tatew., Veg. Apoi p. 85 (1928)-NakaI, Veg. Apoi p. 51 (1930)

f. Raddeana NakaI in Bot. Mag. Tokyo XXV, p. [235] (1911)

Syn. Corydalis Raddeana Reger in Bull. Soc. Imp. Nat. Moscou XXXIV-2, p. $143 \& 145$, tab IV, 10 (1861)-Miyabe et Kudo, Mater. Fl. Hokkaido X, p. 4 (1921)

Nom. Jap. Nagami-no-tsuru-keman (NAKAI).

Hab. in valleys of Mt. Apoi. Fl. Aug.

Dist. sp. Kyushu, Honshu, Yezo, Kuriles, Saghalien, Korea, China, Manchuria, Ochotsk, Ussuri and Amur.

\section{Papaveraceae}

Chelidonium L.

190 (1)*Chelidonium majus Linnaeus, Sp. Pl. ed. 1, I, 505 (1753)-Kudo, Rep. Veg. N. Saghal. p. 141 (1924)-Tatew., Veg. Apoi p. 85 (1928)-NaKaI, Veg. Apoi p. 51 (1930)

var. grandiflorum A. P. de Candolle, Syst. Nat. II, p. 99 (1821)Busci in Fl. Sibir. et Or. Extr. I, p. 11 (1913)

Nom. Jap. Kusa-no-wô.

Hab. in the lower part of Mt. Apoi, Horoidzumi, etc. Fl. May-Jun. Dist. sp. Throughout the world. 